\title{
AC 2011-2000: IMPROVING COMMUNICATION SKILLS: USING PECHAKUCHA STYLE IN ENGINEERING COURSES
}

\section{Sandra Soto-Caban, Muskingum University}

Sandra Soto-Caban received her BSEE and MSEE from University of Puerto Rico, Mayagez Campus, and her $\mathrm{PhD}$ in Electrical Engineering from Michigan State University. She is an Assistant Professor of Engineering at Muskingum University in New Concord, OH. Her interests focus on engineering education and electromagnetics, especially electromagnetic characterization of materials.

\section{Emre Selvi, Muskingum University}

Emre Selvi is an Assistant Professor of Engineering at Muskingum University, New Concord. He received his academic degrees in Mechanical Engineering; B.S. and M.S. from Middle East Technical University and PhD from Texas Tech University. Prior to starting his PhD in 2004, he worked as a Design and Production Engineer for Aselsan Inc. over four years. His research interests are high pressure material science and engineering design, especially as it relate to educational environments.

\section{Ferdinand Avila-Medina, The Ohio State University - Newark}

Ferdinand Avila-Medina is as an adjunct instructor at The Ohio State University - Newark were he works as a Learning Skills Specialist. He has more than twenty years of experience in Higher Education and specializes in student development and retention. 


\title{
Improving Communication Skills: Using PechaKucha Style in Engineering Courses
}

\begin{abstract}
In an effort to improve oral communication skills in engineering students, Muskingum University, a traditional liberal arts institution, tested the PechaKucha presentation style. In this style, students were required to present their design and/or research projects in 6 minutes and forty seconds. The presentation included 20 slides with duration of 20 seconds each. This style was used in two different courses with different kinds of projects. Senior students presented their research project for the Electromagnetics course, and sophomore students used the style to present their design projects in Statics and Dynamics course. After the presentations, students were required to answer a questionnaire were they compared their experience using PechaKucha style with traditional Power Point presentations. Details of the assessment tool and results of the student's questionnaire are presented and explained in detail.
\end{abstract}

\section{Introduction}

Developing effective written and oral communication is essential for college students in every field. The National Association of Colleges and Employers, on its 2011 Job Outlook report, has oral communications skills as the number one non-technical skill required by employers when hiring new employees ${ }^{1}$. In engineering schools, development of students' communications skills is an accreditation criteria established by $\mathrm{ABET}^{2,3}$. In an effort to improve these non-technical skills in engineering students, oral presentations are a requirement throughout the engineering curriculum at Muskingum University, a traditional liberal arts institution.

In our engineering courses we require students to conduct in-class presentations of research and design projects. One of the main problems encountered with that requirement is students' lack of preparation and the ineffective use of PowerPoint as a presentation tool. Too much information on a single slide, lack of preparation or rehearsal, reading from the screen or handouts, and inadequate use of graphics and images are examples of common mistakes found during these presentations. As a result the audience loses interest in the topic and the message conveyed is lost.

To address this problem and improve the students' communications skills we decided to try a different presentation style: PechaKucha ${ }^{4}$.

\section{About PechaKucha}

The PechaKucha style stems from an event called PechaKucha Nights. PechaKucha Nights are informal gatherings in which creative people meet in public to share ideas, thoughts and interests. It started in Tokyo as an event for young designers to meet and share their work. Architects Astrid Klein and Mark Dytham devised it in 2003. 
This presentation style is called PechaKucha 20x20. In the PechaKucha format the presenter must show the audience 20 slides with a presentation time of 20 seconds per slide. The slides are set in auto-forward mode. The goal is to make presentations concise and at a rapid pace.

The creators have trademarked the PechaKucha Nights concept. Any public presentation or event that utilizes PechaKucha 20x20 must be licensed. PechaKucha Nights currently happen in more than 280 cities around the world. The use of the style in education and in office presentations is permitted as long as do not involve public performances.

\section{Implementation and Methodology}

The PechaKucha style was implemented in two engineering courses, Electromagnetics and Statics and Dynamics. In the Electromagnetics course students had to present the results of a research project. Statics and Dynamics students presented the results of a design project. As required by the style, each presentation consisted of 20 slides with duration of 20 seconds each for a total duration of 6 minutes and forty seconds. Each slide consisted of a single image with a phrase or word. No students had used the PechaKucha style before and everybody had prior experience presenting with PowerPoint.

Student's experience with PechaKucha style presentations was assessed using a short questionnaire (see Appendix A). The goal of the survey was to measure the student's perception of the style and their learning experience using it. Two separate surveys were administered to participants. One survey assessed participants' perceptions as presenters and the other assessed their perception as an audience. The questionnaires were given to 15 students, sophomores and seniors, who presented and attended PK style presentations during fall of 2010. It is important to note that this questionnaire was preliminary and a more complete assessment is being planned for future classes.

\section{Results}

Presenter's survey

Presenters responded to questions regarding the following criteria: time spent on preparation and rehearsal; level of difficulty of the style; effectiveness of the style helping understand the content presented; and propensity to use the style in the future. We obtained the following results:

- 10 out of 15 students spent 5 or more hours preparing the slideshow, 3 students spent 4 hours, and 2 spent 3 hours.

The minimum time spent preparing the slideshow was 3 hours. After years of having presentations in different courses and levels, we noticed that this is an improvement. Before, students worked in their presentations the minimum amount of time possible. Many times, they were still working on their presentations while their classmates were presenting. The PK style forced them to choose their pictures and information carefully, helping them in the research process.

- 5 out of 15 students rehearsed for 1 hour, 5 students rehearsed for two hours, 3 for 3 hours, 1 for 4 hours, and 1 student indicated rehearsing for 5 or more hours. 
Rehearse, rehearse, and rehearse. "Death by PowerPoint" is due mostly by lack of rehearsing. PK style needs to be rehearsed. The slides are set in auto-forward mode to make presentations concise and at a rapid pace. For these presentations, all students rehearsed their presentations for at least an hour. This helped them with their confidence and communication skills.

- 12 out of 15 students said that the PK style helped them understanding the material better. 2 students answered that question as neutral, meaning that the PK style was not better than the traditional style for material understanding. Only 1 student said that the PK style didn't help in understanding the material.

As indicated before, one of the main problems encountered with oral presentations is that frequently the presenters addressed their audience without rehearsal or under-rehearsed. With the PK style, students spent, at least 4 hours working on their presentations. Since they need to rehearse their "script" and talk only about the most important points of their project, they are forced to study the material resulting in a better understanding of the problem.

- 7 out of 15 students indicated that preparing a PK style presentation was harder than a traditional style presentation. 5 students found it as hard as any presentation style, and for 3 students the PK style was easier.

Students found the PK style presentation harder to prepare than the traditional style. Based on the answers given by the students in the different courses, students that used PK style to present their research project found it easier to implement than the students with the design problem. Students with the design problem had a really hard time trying to accommodate all their equations and information in the $20 \times 20$ format.

- 12 out of 15 students indicated that for their next presentation they prefer to use PK style. The other 3 students preferred the traditional style of presentation.

Regardless that the PK style was harder to prepare and they needed more time to prepare for their presentations, students said that they prefer this style over the traditional style for research projects.

Overall, students liked the PK style and indicated that they will like to use it in their next presentation.

\section{Audience's survey}

The second survey was intended to measure the audience's perception of: the presenter's ability to deliver the presentation; sustainability of interest; preference between simple images vs. bulleted text; and preference of PK style compared to traditional PowerPoint presentations. According to the survey's results:

- 9 out of 15 students indicated that the PK style helped them understand the material presented better. The other 6 students were neutral in that question.

Most of the students (11 out of 15) were sophomores attending a senior's research presentations. Results indicated that the PK style helped a majority of the students in understanding the information presented. This is in comparison with the traditional style. 
- 10 out of 15 students in the audience indicated that they liked the pace and format of the presentations. 2 were neutral and 3 students in the audience didn't like the form used for presenting the material.

$67 \%$ of the students in the audience indicated that they liked the pace and format of the presentations. This doesn't reflect that they learned something from the presentation, but they found the presentations entertaining.

- 11 out of 15 students in the audience said that the PK style presentations kept their attention and interest during the whole time. 3 answered neutral and 1 student indicated that the presentations didn't keep his/her attention.

The PK style was able to keep the attention and interest of the audience for most of the time. The fast pace and format of the presentation was not boring for them. Also, they indicated that the presenters were more confident presenting and that capture their attention.

- About their preferred style of presentation to attend, 14 students said that they prefer to attend a PK style presentation over a traditional style. Only 1 student preferred the traditional style of presentation.

Almost the complete audience indicated that is more fun to attend a PK style presentation than a traditional one.

\section{Student's comments}

The survey included a section with open-ended questions. This section was optional for the students. Here are some of the comments:

1. Please write any issues encountered using the PechaKucha style.

- "No issues, just more preparation."

- "The biggest issue was trying to decide what info was most important to put in the presentation."

- "Keeping time with the 20 s slides."

. "I don't believe PK style works well for groups."

. "I thought PK was really cool."

2. Was it helpful for you? How?

- "Yes. It really forces you to really know the material since you have no bullets, just images. It made me feel more prepared."

- "I had to think about what I wanted to say both before and during the presentation."

- "Yes, it was very helpful, because it gave more freedom to present the material, and it allowed me to better manage and understand."

- "It is helpful for me. First, I think we make our own PPT more refined in this way, and also, it is a good way to practice and improve our speech skills."

3. What do you think are the advantages/disadvantages of the Pecha Kucha style?

- "It is more refined. Easier to understand."

- "Timing is the very big problem. Control of the time is very hard."

- "It is faster paced and easier to pay attention to." 
- "Slides can be more interesting."

. "Keeps audience interested."

\section{General comments}

- "I like the PK style more when presenting and listening and would like to do that more in the future."

- "Good method. Useful."

- "We can try to use it several times in the future."

- "It was fun and more relaxed and educational."

• "Overall, it was fun."

Most of the student's comments agreed in that the PK style helped them understanding the material better, keeps the audience interested, and it was fun to do. They wanted to do it again in other courses.

\section{Instructors' assessment and comments}

A rubric was prepared for the assessment of the presentations. The rubric used in the Electromagnetics course is included in Appendix B. A similar one was used in the Statics and Dynamics course. The presentations were graded using the following criteria:

- Organization

- Content

- Creativity

- Presentation style

- Use of language: word choice, voice
- Grammar

- Eye contact

- Audience interaction, Q\&A

- Audience response

- Length of presentation

This rubric is similar to the rubric used to assess traditional style presentations, except in the presentation style criterion that was added to assess the PK style of presentation. Results from this assessment reflect that the students had better scores in creativity, eye contact, audience interaction, audience response and organization than previous scores obtained in a traditional presentation. The PK style forces the presenter to shy away from technical details, consequently content was not as good for students presenting their design projects. That was not the case for the research projects.

Overall, students were better prepared for their presentations and the PK style was well accepted by the students. Based on this particular experience we agreed with the students' perception that the style is more convenient for research presentations than for design projects. For design project presentations, the traditional style gives more space to the students to present their equations, procedure, and final designs. At this time, we think that the PK style is more useful for small projects, lab presentations, and research projects throughout the curriculum to improve student's communication skills. Due to the small sample used for this research, we'll be replicating the experiment in future courses to validate our perceptions.

\section{Conclusions}


Informal interviews conducted with students prior to the PK presentations showed that in previous presentations students didn't rehearse or practice their presentations. Our personal evaluations of previous presentations show that the majority of the students present their topics reading directly from the slides or from handouts, making the presentation ineffective and boring.

After having two different courses presenting their research and design projects using the PechaKucha style, our results suggest that the PK style can positively contribute to the development of communication skills in our students. The results showed that students enjoyed concise and fast pace presentations over traditional method of classroom presentations.

Results for the individual courses implied that the PK style was more appropriate for research presentations than for design presentations. In general, the style helped the students in their communications skills and in the educational purpose of the presentation. Since this study was performed with a limited amount of data, it will be repeated and a more complete assessment is planned for future classes.

\section{Bibliography}

1. Job Outlook 2011. National Association of Colleges and Employers, Bethlehem, PA, November 2010.

2. Ford, J.D. and Riley, L.A., "Integrating Communication and Engineering: A look at curricula, courses and support systems”, Journal of Engineering Education, October 2003.

3. Williams, J.M., “Transformations in Technical Communication Pedagogy: engineering, writing, and the ABET Engineering Criteria 2000”, Proceedings of 2000 Joint IEEE International and 18th Annual Conference on Computer Documentation, Cambridge, MA, Sept. 2000.

4. Klein Dytham Architecture, "PechaKucha 20x20", [http://www.pecha-kucha.org]. 


\section{Appendix A}

\section{Pecha Kucha Presentations Survey Form}

\section{PRESENTER}

1) What kind of project did you present?
a) Research
b) Design

2) How many hours did you spend preparing your presentation? (choosing the pictures, preparing the slides, etc.)
a) 1
b) 2
c) 3
d) 4
e) $5+$

3) Compared to previous presentations you've done, preparing the presentation using Pecha Kucha style was
a) Easier
b) Harder
c) The same

4) How many hours did you spend rehearsing your presentation?
a) 1
b) 2
c) 3
d) 4
e) $5+$

5) Compared to traditional presentation style, the Pecha Kucha style helped me understand the material to be presented better.
a) Completely agree
b) Agree
c) Neutral
d) Disagree
e) Completely disagree

6) The next time you have to present a project, which format will you prefer?

a) Pecha Kucha style

b) Traditional presentation style 


\section{AUDIENCE}

1) What kind of project presentation did you attend?
a) Research
b) Design

2) The presenters' speaking pace was clear, understandable, and fluent.
a) Completely agree
b) Agree
c) Neutral
d) Disagree
e) Completely disagree

3) The content was presented in a way that maintained my interest.
a) Completely agree
b) Agree
c) Neutral
d) Disagree
e) Completely disagree

4) The use of images instead of bulleted text helped me understanding the presenter's topic.
a) Completely agree
b) Agree
c) Neutral
d) Disagree
e) Completely disagree

5) As part of an audience in a presentation, which format will you prefer?
a) Pecha Kucha style
b) Traditional presentation style 


\section{FEEDBACK}

Please write any issues you encountered using the Pecha Kucha style.

Was it helpful for you? How?

What do you think are the advantages/disadvantages of the Pecha Kucha style?

General comments.

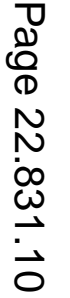




\section{Appendix B - Rubric}

\section{Oral Presentation Rubric}

PK Style

\begin{tabular}{|c|c|c|c|c|c|}
\hline Criteria & Distinguished (3) & Proficient (2) & Basic (1) & Unacceptable (0) & Points \\
\hline \multirow{5}{*}{ Organization } & $\begin{array}{c}\text { Extremely well } \\
\text { organized. }\end{array}$ & $\begin{array}{c}\text { Generally well } \\
\text { organized. }\end{array}$ & Somewhat organized. & $\begin{array}{c}\text { Poor or non-existent } \\
\text { organization }\end{array}$ & \\
\hline & $\begin{array}{l}\text { Introduces the } \\
\text { purpose of the } \\
\text { presentation } \\
\text { clearly and } \\
\text { creatively. }\end{array}$ & $\begin{array}{l}\text { Introduces the } \\
\text { purpose of the } \\
\text { presentation } \\
\text { clearly. }\end{array}$ & $\begin{array}{l}\text { Introduces the } \\
\text { purpose of the } \\
\text { presentation. }\end{array}$ & $\begin{array}{l}\text { Does not clearly } \\
\text { introduce the } \\
\text { purpose of the } \\
\text { presentation. }\end{array}$ & \\
\hline & $\begin{array}{c}\text { Effectively } \\
\text { includes smooth, } \\
\text { clever transitions } \\
\text { which are succinct } \\
\text { but not choppy in } \\
\text { order to connect } \\
\text { key points }\end{array}$ & $\begin{array}{l}\text { Include transitions } \\
\text { to connect key } \\
\text { points but better } \\
\text { transitions from } \\
\text { idea to idea are } \\
\text { noted. }\end{array}$ & $\begin{array}{l}\text { Includes some } \\
\text { transitions to connect } \\
\text { key points but there } \\
\text { is difficulty in } \\
\text { following } \\
\text { presentation. }\end{array}$ & $\begin{array}{l}\text { Uses ineffective } \\
\text { transitions that } \\
\text { rarely connect } \\
\text { points; cannot } \\
\text { understand } \\
\text { presentation because } \\
\text { there is no sequence } \\
\text { for information. }\end{array}$ & \\
\hline & $\begin{array}{l}\text { Student presents } \\
\text { information in } \\
\text { logical, interesting } \\
\text { sequence which } \\
\text { audience can } \\
\text { follow. }\end{array}$ & $\begin{array}{l}\text { Most information } \\
\text { presented in } \\
\text { logical sequence; } \\
\text { A few minor } \\
\text { points may be } \\
\text { confusing } \\
\end{array}$ & $\begin{array}{l}\text { Student jumps } \\
\text { around topics. } \\
\text { Several points are } \\
\text { confusing. }\end{array}$ & $\begin{array}{l}\text { Presentation is } \\
\text { choppy and } \\
\text { disjointed; no } \\
\text { apparent logical } \\
\text { order of presentation }\end{array}$ & \\
\hline & $\begin{array}{c}\text { Ends with an } \\
\text { accurate } \\
\text { conclusion } \\
\text { showing } \\
\text { thoughtful, strong } \\
\text { evaluation of the } \\
\text { evidence } \\
\text { presented. }\end{array}$ & $\begin{array}{l}\text { Ends with a } \\
\text { summary of main } \\
\text { points showing } \\
\text { some evaluation of } \\
\text { the evidence } \\
\text { presented. }\end{array}$ & $\begin{array}{c}\text { Ends with a summary } \\
\text { or conclusion; little } \\
\text { evidence of } \\
\text { evaluating content } \\
\text { based on evidence. }\end{array}$ & $\begin{array}{l}\text { Ends without a } \\
\text { summary or } \\
\text { conclusion. }\end{array}$ & \\
\hline \multirow[b]{2}{*}{ Content } & $\begin{array}{c}\text { Clearly identifies } \\
\text { and states ethical } \\
\text { issues. }\end{array}$ & $\begin{array}{l}\text { Identifies ethical } \\
\text { issues but not } \\
\text { states them in } \\
\text { good manner. }\end{array}$ & $\begin{array}{c}\text { Poorly identifies and } \\
\text { states an ethical } \\
\text { issue. }\end{array}$ & $\begin{array}{c}\text { Does not identify } \\
\text { and state any ethical } \\
\text { issue. }\end{array}$ & \\
\hline & $\begin{array}{c}\text { Good use of } \\
\text { ethical } \\
\text { codes/standards or } \\
\text { the theories } \\
\text { discussed in the } \\
\text { class while } \\
\text { discussing the } \\
\text { issue.(Ethical } \\
\text { analysis) }\end{array}$ & $\begin{array}{c}\text { Average use of } \\
\text { ethical } \\
\text { codes/standards or } \\
\text { the theories } \\
\text { discussed in the } \\
\text { class while } \\
\text { discussing the } \\
\text { issue. }\end{array}$ & $\begin{array}{l}\text { Poor/wrong use of } \\
\text { ethical } \\
\text { codes/standards or } \\
\text { the theories discussed } \\
\text { in the class while } \\
\text { discussing the issue. }\end{array}$ & $\begin{array}{l}\text { No use of ethical } \\
\text { codes/standards or } \\
\text { the theories } \\
\text { discussed in the } \\
\text { class while } \\
\text { discussing the issue. }\end{array}$ & \\
\hline Content & $\begin{array}{c}\text { Clear and } \\
\text { complete } \\
\text { understanding of } \\
\text { the } \\
\text { design/problem } \\
\text { presented. } \\
\text { Applications of }\end{array}$ & $\begin{array}{c}\text { Sound } \\
\text { understanding of } \\
\text { the problem. Some } \\
\text { helpful } \\
\text { applications of EM } \\
\text { theory are } \\
\text { included. }\end{array}$ & $\begin{array}{c}\text { Serious deficiencies } \\
\text { understanding the } \\
\text { problem. } \\
\text { Explanations of } \\
\text { concepts and/or } \\
\text { theories are } \\
\text { inaccurate or }\end{array}$ & $\begin{array}{l}\text { No evidence of } \\
\text { understanding of the } \\
\text { problem. No } \\
\text { reference is made to } \\
\text { EM theory. }\end{array}$ & \\
\hline
\end{tabular}




\begin{tabular}{|c|c|c|c|c|}
\hline & $\begin{array}{c}\text { EM theory are } \\
\text { included to } \\
\text { illuminate issues. }\end{array}$ & & $\begin{array}{l}\text { incomplete. Little } \\
\text { attempt is made to tie } \\
\text { in EM theory. }\end{array}$ & \\
\hline & $\begin{array}{l}\text { Discusses all the } \\
\text { points indicated in } \\
\text { the assignment. }\end{array}$ & $\begin{array}{l}\text { Discusses most of } \\
\text { the points } \\
\text { indicated in the } \\
\text { assignment. }\end{array}$ & $\begin{array}{l}\text { Discusses some of } \\
\text { the points indicated } \\
\text { in the assignment. }\end{array}$ & $\begin{array}{l}\text { Discusses none of } \\
\text { the points indicated } \\
\text { in the assignment. }\end{array}$ \\
\hline Creativity & $\begin{array}{c}\text { Uses the } \\
\text { unexpected to full } \\
\text { advantage; very } \\
\text { original, clever, } \\
\text { and creative } \\
\text { approach that } \\
\text { captures } \\
\text { audience's } \\
\text { attention. }\end{array}$ & $\begin{array}{c}\text { Some originality } \\
\text { apparent; clever at } \\
\text { times; good } \\
\text { variety and } \\
\text { blending of } \\
\text { materials/media. }\end{array}$ & $\begin{array}{c}\text { Little or no variation; } \\
\text { a few original } \\
\text { touches but for the } \\
\text { most part material } \\
\text { presented with little } \\
\text { originality or } \\
\text { interpretation. }\end{array}$ & $\begin{array}{l}\text { Bland, predictable, } \\
\text { and lacked "zip". } \\
\text { Repetitive with little } \\
\text { or no variety; little } \\
\text { creative energy } \\
\text { used. }\end{array}$ \\
\hline \multirow{3}{*}{$\begin{array}{l}\text { Presentation } \\
\text { style }\end{array}$} & $\begin{array}{r}20 \text { slides } \times 20 \\
\text { seconds each } \\
\end{array}$ & $\begin{array}{c}\text { Less or more than } \\
20 \text { slides } \times 20 \\
\text { seconds each }\end{array}$ & $\begin{array}{c}\text { Less or more than } 20 \\
\text { seconds per slide }\end{array}$ & $\begin{array}{l}\text { Didn't follow the } \\
\text { PK style at all }\end{array}$ \\
\hline & $\begin{array}{c}\text { Visual aids were } \\
\text { appropriate, } \\
\text { colorful, and large } \\
\text { enough to be seen } \\
\text { by all, even those } \\
\text { in back of the } \\
\text { class. }\end{array}$ & $\begin{array}{l}\text { Visual aids were } \\
\text { appropriate. Font } \\
\text { size is appropriate } \\
\text { for reading. }\end{array}$ & $\begin{array}{c}\text { Some visual aids } \\
\text { were not appropriate. } \\
\text { Font is too small to } \\
\text { be easily seen. }\end{array}$ & $\begin{array}{l}\text { Visuals not related } \\
\text { to the topic. Font is } \\
\text { too small to be seen. }\end{array}$ \\
\hline & $\begin{array}{c}\text { Narrative is } \\
\text { perfectly } \\
\text { synchronized with } \\
\text { the slides. Right } \\
\text { amount of } \\
\text { information is } \\
\text { given. }\end{array}$ & $\begin{array}{c}\text { Some slides were } \\
\text { not in time with } \\
\text { the narrative, but } \\
\text { the overall timing } \\
\text { was good. }\end{array}$ & $\begin{array}{l}\text { Slides not in time } \\
\text { with the narrative. } \\
\text { Silent moments } \\
\text { between slides. }\end{array}$ & Totally out of phase. \\
\hline $\begin{array}{c}\text { Use of } \\
\text { Language: } \\
\text { Word Choice, } \\
\text { Voice }\end{array}$ & $\begin{array}{l}\text { Poised, clear } \\
\text { articulation; } \\
\text { proper volume; } \\
\text { steady rate; } \\
\text { enthusiasm; } \\
\text { confidence; } \\
\text { speaker is clearly } \\
\text { comfortable in } \\
\text { front of the group. }\end{array}$ & $\begin{array}{c}\text { Clear articulation } \\
\text { but not as } \\
\text { polished; slightly } \\
\text { uncomfortable at } \\
\text { times Most can } \\
\text { hear presentation. }\end{array}$ & $\begin{array}{c}\text { Audience } \\
\text { occasionally has } \\
\text { trouble hearing the } \\
\text { presentation; seems } \\
\text { uncomfortable. }\end{array}$ & $\begin{array}{l}\text { Presenter is } \\
\text { obviously anxious } \\
\text { and cannot be heard } \\
\text { or monotone with } \\
\text { little or no } \\
\text { expression. }\end{array}$ \\
\hline Grammar & $\begin{array}{l}\text { Presentation has } \\
\text { no misspellings or } \\
\text { grammatical } \\
\text { errors. }\end{array}$ & $\begin{array}{l}\text { Presentation has } \\
\text { no more than two } \\
\text { misspellings } \\
\text { and/or } \\
\text { grammatical errors }\end{array}$ & $\begin{array}{l}\text { Presentation has } \\
\text { three misspellings } \\
\text { and/or grammatical } \\
\text { errors. }\end{array}$ & $\begin{array}{c}\text { Student's } \\
\text { presentation has } \\
\text { four or more } \\
\text { spelling errors } \\
\text { and/or grammatical } \\
\text { errors. } \\
\end{array}$ \\
\hline Eye Contact & $\begin{array}{l}\text { Maintains eye } \\
\text { contact; seldom } \\
\text { returning to notes; } \\
\text { presentation is like } \\
\text { a planned } \\
\text { conversation. }\end{array}$ & $\begin{array}{l}\text { Student maintains } \\
\text { eye contact most } \\
\text { of the time but } \\
\text { frequently returns } \\
\text { to notes. }\end{array}$ & $\begin{array}{l}\text { Some eye contact, } \\
\text { but not maintained } \\
\text { and at least half the } \\
\text { time reads most of } \\
\text { report. }\end{array}$ & $\begin{array}{l}\text { Student reads all or } \\
\text { most of report with } \\
\text { no eye contact. }\end{array}$ \\
\hline
\end{tabular}




\begin{tabular}{|c|c|c|c|c|}
\hline & $\begin{array}{c}\text { Encourages } \\
\text { audience } \\
\text { interaction. Calls } \\
\text { on classmates by } \\
\text { name. }\end{array}$ & $\begin{array}{l}\text { Encourages } \\
\text { audience } \\
\text { interaction. }\end{array}$ & $\begin{array}{l}\text { Reluctantly interacts } \\
\text { with audience. }\end{array}$ & $\begin{array}{c}\text { Avoids or } \\
\text { discourages active } \\
\text { audience } \\
\text { participation. }\end{array}$ \\
\hline $\begin{array}{c}\text { Audience } \\
\text { Interaction, } \\
\text { Questions and } \\
\text { Answers. }\end{array}$ & $\begin{array}{l}\text { Demonstrates } \\
\text { extensive } \\
\text { knowledge of the } \\
\text { topic by } \\
\text { responding } \\
\text { confidently, } \\
\text { precisely and } \\
\text { appropriately to all } \\
\text { audience } \\
\text { questions. }\end{array}$ & $\begin{array}{c}\text { Demonstrates } \\
\text { knowledge of the } \\
\text { topic by } \\
\text { responding } \\
\text { accurately and } \\
\text { appropriately } \\
\text { addressing } \\
\text { questions. At ease } \\
\text { with answers to all } \\
\text { questions but fails } \\
\text { to elaborate. }\end{array}$ & $\begin{array}{c}\text { Demonstrates some } \\
\text { knowledge of } \\
\text { rudimentary } \\
\text { questions by } \\
\text { responding } \\
\text { accurately to } \\
\text { questions. }\end{array}$ & $\begin{array}{l}\text { Demonstrates } \\
\text { incomplete } \\
\text { knowledge of the } \\
\text { topic by responding } \\
\text { inaccurately and } \\
\text { inappropriately to } \\
\text { questions. }\end{array}$ \\
\hline $\begin{array}{l}\text { Audience } \\
\text { Response }\end{array}$ & $\begin{array}{l}\text { Involved the } \\
\text { audience in the } \\
\text { presentation; held } \\
\text { the audience's } \\
\text { attention } \\
\text { throughout. }\end{array}$ & $\begin{array}{l}\text { Presented facts } \\
\text { with some } \\
\text { interesting } \\
\text { "twists"; held the } \\
\text { audience's } \\
\text { attention most of } \\
\text { the time. }\end{array}$ & $\begin{array}{l}\text { Some related facts } \\
\text { but went off topic } \\
\text { and lost the audience. }\end{array}$ & $\begin{array}{l}\text { Incoherent; } \\
\text { audience lost } \\
\text { interest. }\end{array}$ \\
\hline $\begin{array}{c}\text { Length of } \\
\text { Presentation }\end{array}$ & $\begin{array}{l}6 \text { minutes } 40 \\
\text { seconds }\end{array}$ & $\begin{array}{l}6 \text { minutes } 40 \\
\text { seconds }+/-5 \\
\text { seconds }\end{array}$ & $\begin{array}{l}6 \text { minutes } 40 \text { seconds } \\
+/-10 \text { seconds }\end{array}$ & $\begin{array}{c}20 \text { or more seconds } \\
\text { above or below the } \\
\text { allotted time }\end{array}$ \\
\hline
\end{tabular}

\section{Total points:}

